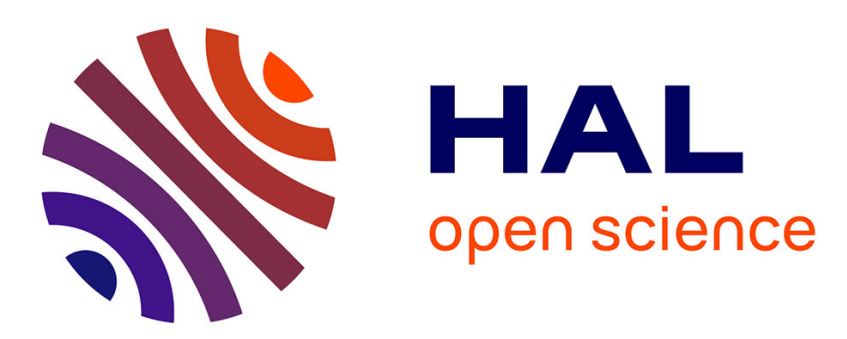

\title{
Fluid circulation at Stromboli volcano (Aeolian Islands, Italy) from self-potential and CO2 surveys.
}

Anthony Finizola, Francesco Sortino, Jean-François Lénat, Mariano Valenza

\section{To cite this version:}

Anthony Finizola, Francesco Sortino, Jean-François Lénat, Mariano Valenza. Fluid circulation at Stromboli volcano (Aeolian Islands, Italy) from self-potential and CO2 surveys.. Journal of Volcanology and Geothermal Research, 2002, 116, pp.1-18. hal-01452542

\section{HAL Id: hal-01452542 \\ https://hal.science/hal-01452542}

Submitted on 2 Feb 2017

HAL is a multi-disciplinary open access archive for the deposit and dissemination of scientific research documents, whether they are published or not. The documents may come from teaching and research institutions in France or abroad, or from public or private research centers.
L'archive ouverte pluridisciplinaire HAL, est destinée au dépôt et à la diffusion de documents scientifiques de niveau recherche, publiés ou non, émanant des établissements d'enseignement et de recherche français ou étrangers, des laboratoires publics ou privés. 


\title{
Fluid circulation at Stromboli volcano (Aeolian Islands, Italy) from self-potential and $\mathrm{CO}_{2}$ surveys
}

\author{
Anthony Finizola ${ }^{a, *}$, Francesco Sortino ${ }^{b}, \mathrm{~J}$ ean-Franøis Lénat ${ }^{\mathrm{a}}$, \\ Mariano Valenza ${ }^{b, c}$ \\ a Laboratoire Magmas et Volcans, OPGC, Université Blaise Pascal-CNRS, 5 rue Kessler, 63038 Clermont-Ferrand, France \\ b Istituto Nazionale di Geofisica e Vulcanologia, Via Ugo La Malfa 153, 90144 Palermo, Italy \\ c Università di Palermo, Dipartimento di Chimica e Fisica della Terra e Applicazioni, Via Archirafi 36, 90123 Palermo, Italy
}

\begin{abstract}
This work addresses the study of fluid circulation of the Stromboli island using a dense coverage of self-potential (SP) and soil $\mathrm{CO}_{2}$ data. A marked difference exists between the northern flank and the other flanks of the island. The northern flank exhibits (1) a typical negative SP/altitude gradient not observed on the other flanks, and (2) higher levels of $\mathrm{CO}_{2}$. The general SP pattern suggests that the northern flank is composed of porous layers through which vadose water flows down to a basal water table, in contrast to the other flanks where impermeable layers impede the vertical flow of vadose water. In the Sciara del Fuoco and Rina Grande-Le Schicciole landslide complexes, breccias of shallow gliding planes may constitute such impermeable layers whereas elsewhere, poorly permeable, fine-grained pyroclastites or altered lava flows may be present. This general model of the flanks also explains the main $\mathrm{CO}_{2}$ patterns: concentration of $\mathrm{CO}_{2}$ at the surface is high on the porous north flank and lower on the other flanks where impermeable layers can block the upward $\mathrm{CO}_{2}$ flux. The active upper part of the island is underlain by a well-defined hydrothermal system bounded by short-wavelength negative SP anomalies and high peaks of $\mathrm{CO}_{2}$. These boundaries coincide with faults limiting ancient collapses of calderas, craters and flank landslides. The hydrothermal system is not homogeneous but composed of three main subsystems and of a fourth minor one and is not centered on the active craters. The latter are located near its border. This divergence between the location of the active craters and the extent of the hydrothermal system suggests that the internal heat sources may not be limited to sources below the active craters. If the heat source strictly corresponds to intrusions at depth around the active conduits, the geometry of the hydrothermal subsystems must be strongly controlled by heterogeneities within the edifice such as craters, caldera walls or gliding planes of flank collapse, as suggested by the correspondence between $\mathrm{SP}-\mathrm{CO}_{2}$ anomalies and structural limits. The inner zone of the hydrothermal subsystems is characterized by positive SP anomalies, indicating upward movements of fluids, and by very low values of $\mathrm{CO}_{2}$ emanation. This pattern suggests that the hydrothermal zone becomes self-sealed at depth, thus creating a barrier to the $\mathrm{CO}_{2}$ flux. In this hypothesis, the observed hydrothermal system is a shallow one and it involves mostly convection of infiltrated meteoric water above the sealed zone. Finally, on the base of $\mathrm{CO}_{2}$ degassing measurements, we present evidence for the presence of two regional faults, oriented $\mathrm{N} 41^{\circ}$ and $\mathrm{N} 64^{\circ}$, and decoupled from the volcanic structures. (C) 2002 Elsevier Science B.V. All rights reserved.
\end{abstract}

\footnotetext{
* Corresponding author. Tel: +33-473-346-746; Fax: +33-473-346-744. E-mail address: A.Finizola@opgc.univ-bpclermont.fr (A. Finizola).
} 


\section{Introduction}

Several self-potential (SP) studies on active volcanoes show the presence of positive anomalies, a few hundreds to thousands $\mathrm{mV}$ in amplitude, associated with hydrothermal or active zones. The anomalies are usually observed in the upper part and summit crater area of the edifices (e.g. Dana, 1992; Patella, 1997; Di Maio et al., 1998; Finizola et al., 1998; Lénat et al., 1998) or on the flanks over lateral vents, magma intrusions, eruptive fissures or rift zones (e.g. Aubert and Kieffer, 1984; Di Maio and Patella, 1994; Di Maio et al., 1994; Jackson and Kauahikaua, 1987; Malengreau et al., 1994; Zablocki, 1976; Zlotnicki et al., 1994). Two main mechanisms have been proposed to explain the SP anomalies above hydrothermal zones: electrokinetic and thermoelectric couplings (Corwin and Hoover, 1979). The two phenomena can coexist since the heat sources (magma bodies) generating thermoelectric potentials also create hydrothermal convective cells giving rise to electrokinetic (streaming) potentials. Theoretical considerations suggest that electrokinetic potentials are significantly larger than thermoelectric potentials (Corwin and Hoover, 1979). For shallow hydrothermal systems, where hot steam flux reaches or condenses near the surface, surveys have shown a good correlation between SP and temperature maxima (Ballestracci, 1982; Nishida and Tomiya, 1987; Aubert and Baubron, 1988; Matsushima et al., 1990; Aubert, 1999). The SP method is therefore frequently used on active volcanoes to evidence the hydrothermal systems and outline their extension.

On the other hand, the measure of soil gases is widely used to study the relationship between gas emanations and tectonic fractures of the lithosphere at various scales (Irwin and Barnes, 1980; Sugisaki et al., 1983; Klusman, 1993). Generally higher permeability along fractured rocks drains rising gas, giving rise to soil gas concentration anomalies at the surface. In volcanic environments, large anomalies of $\mathrm{CO}_{2}$ (the most abun- dant magmatic gas next to water) are sometimes observed near active vents (Allard et al., 1991; Anza et al., 1993; Williams-Jones et al., 2000) or along tectonic faults (D'Alessandro et al., 1992; Giammanco et al., 1997; Azzaro et al., 1998; Etiope et al., 1999).

Because Stromboli is an isolated volcano characterized by permanent activity and continuous degassing, it can be considered as an outstanding site to study fluid circulation. For this reason, we carried out $\mathrm{SP}$ and $\mathrm{CO}_{2}$ surveys over the island. Data interpretation focuses on two aspects: (i) the analysis of SP and $\mathrm{CO}_{2}$ anomalies in terms of structural control of fluids circulation and (ii) the relation between SP anomalies and geology.

\section{Geological setting}

The island of Stromboli is located in the Tyrrhenian Sea, in the northernmost part of the Aeolian archipelago. Surveys carried out in the submarine Stromboli-Panarea area recognized a regional NE-SW structural trend (Gabbianelli et al., 1993). Similar orientations were documented in the emerged part of Stromboli island, principally in eruptive fissure and dike orientations (Zanchi and Francalanci, 1989; Pasquarè et al., 1993, Fig. 1). Geological investigations (Rosi, 1980; Francalanci, 1987; Zanchi and Francalanci, 1989; Keller et al., 1993) lead us to define seven phases in the subaerial evolution of Stromboli island during the last $100 \mathrm{kyr}$ : (1) PaleoStromboli I (PST I), (2) PaleoStromboli II (PST II), (3) PaleoStromboli III (PST III), (4) Scari complex, (5) Vancori Period, (6) NeoStromboli and (7) Recent Stromboli. The different stages are separated either by erosional deposits or by caldera or flank collapses (Pasquarè et al., 1993; Hornig-Kjarsgaard et al., 1993). The first caldera collapse, PST I caldera, occurred at the end of the PST I cycle. Its limit may be observed in the south part of the island between Gramigna and Punta Lena ( 1 in Fig. 1) and is buried by subsequent activity 


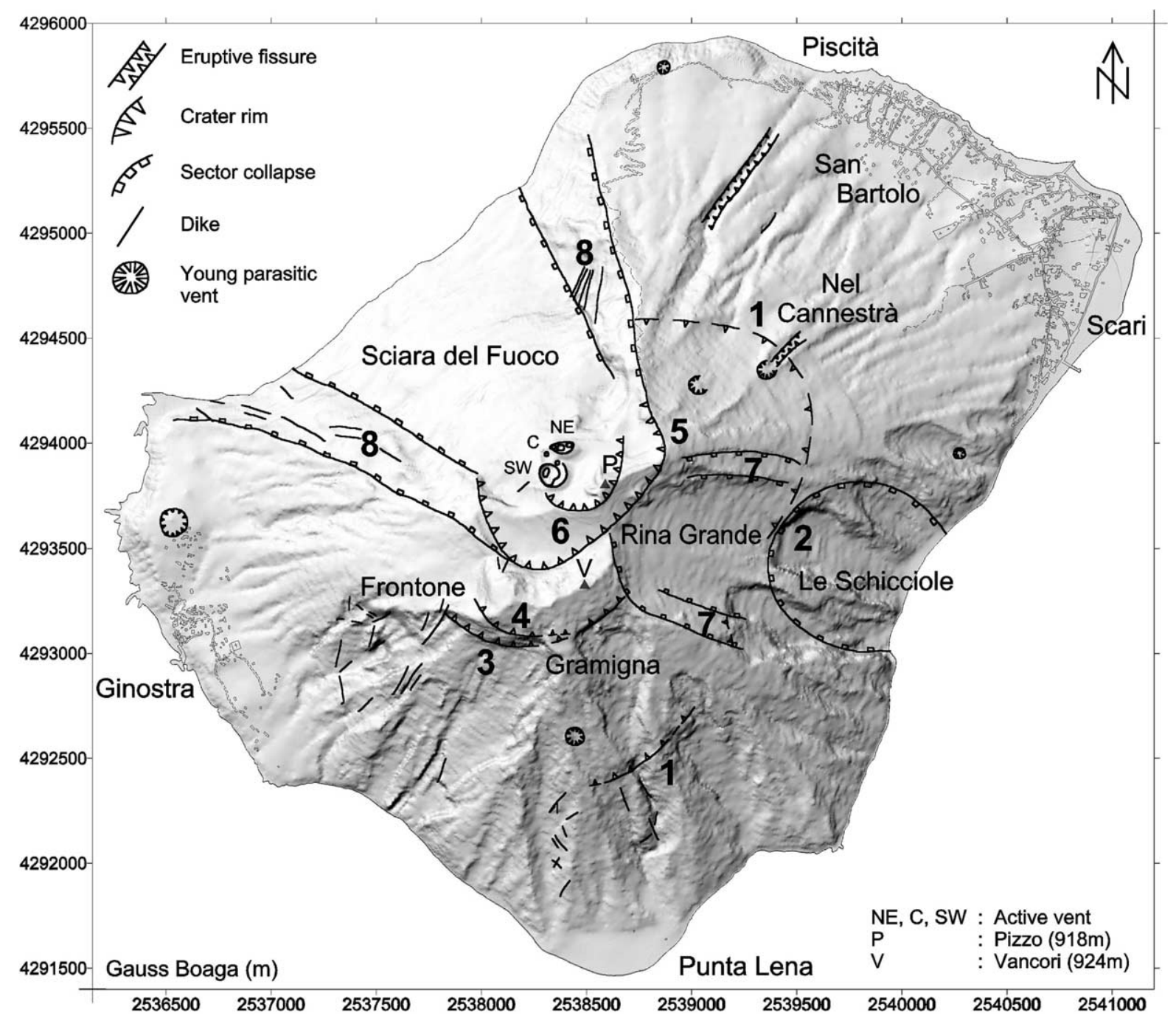

Fig. 1. Map of Stromboli island showing the main volcano-structural features superimposed on shaded topography (illumination from the NW). Numbers designate structures discussed in the text (after Pasquarè et al., 1993; Keller et al., 1993, modified).

elsewhere. A change of slope at the NE of the summit area is tentatively interpreted as the continuation of the PST I caldera. The second caldera collapse, at the end of the PST III cycle, is only observable between Gramigna and Frontone (3 in Fig. 1). The Schicciole flank collapse ( 2 in Fig. 1) is thought to have formed at the east during the same period. A last caldera collapse, visible only above the outcrop of PST III caldera limit (4 in Fig. 1), occurred at the transition between the lower and middle Vancori cycle. Subsequently, the volcano was affected by two flank landslides, Rina Grande and Sciara del Fuoco (7, 8, respectively, in Fig. 1), and two identified crater collapses (5, 6 in Fig. 1) (Pasquarè et al., 1993). The Sciara del Fuoco formed about 5000 years ago and is the more recent scar from a series of landslides affecting this flank of the island over 13000 years. During the same period $(\sim 6000$ year BP), two effusive events occurred outside the structural limits of the Sciara del Fuoco, from an eruptive fissure and a lateral vent located above Nel Cannestrà, in the northern part of the island. Since at least 2000 years ago, Stromboli 
has had a persistent mild explosive activity with periodic lava flows inside the Sciara del Fuoco depression and violent explosions causing threat to large parts of the island. The vents of historical lava flows are always located at a lower elevation than the present crater platform.

\section{Data acquisition and processing}

SP measurements and soil-gas sampling were performed during a field campaign in July-August 1999 and in May 2000. SP measurements and soilgas sampling were carried out contemporaneously and at the same locations. Data were taken every $20 \mathrm{~m}$ along six radial profiles extending from the summit to the sea (Fig. 2): the Ginostra, Punta Lena, Le Schicciole, Scari, Piscità and Sciara del Fuoco profiles. Two short additional profiles are located between the Scari and Le Schicciole profiles and near the SW border of Sciara del Fuoco. The SP equipment consisted of a high-impedance

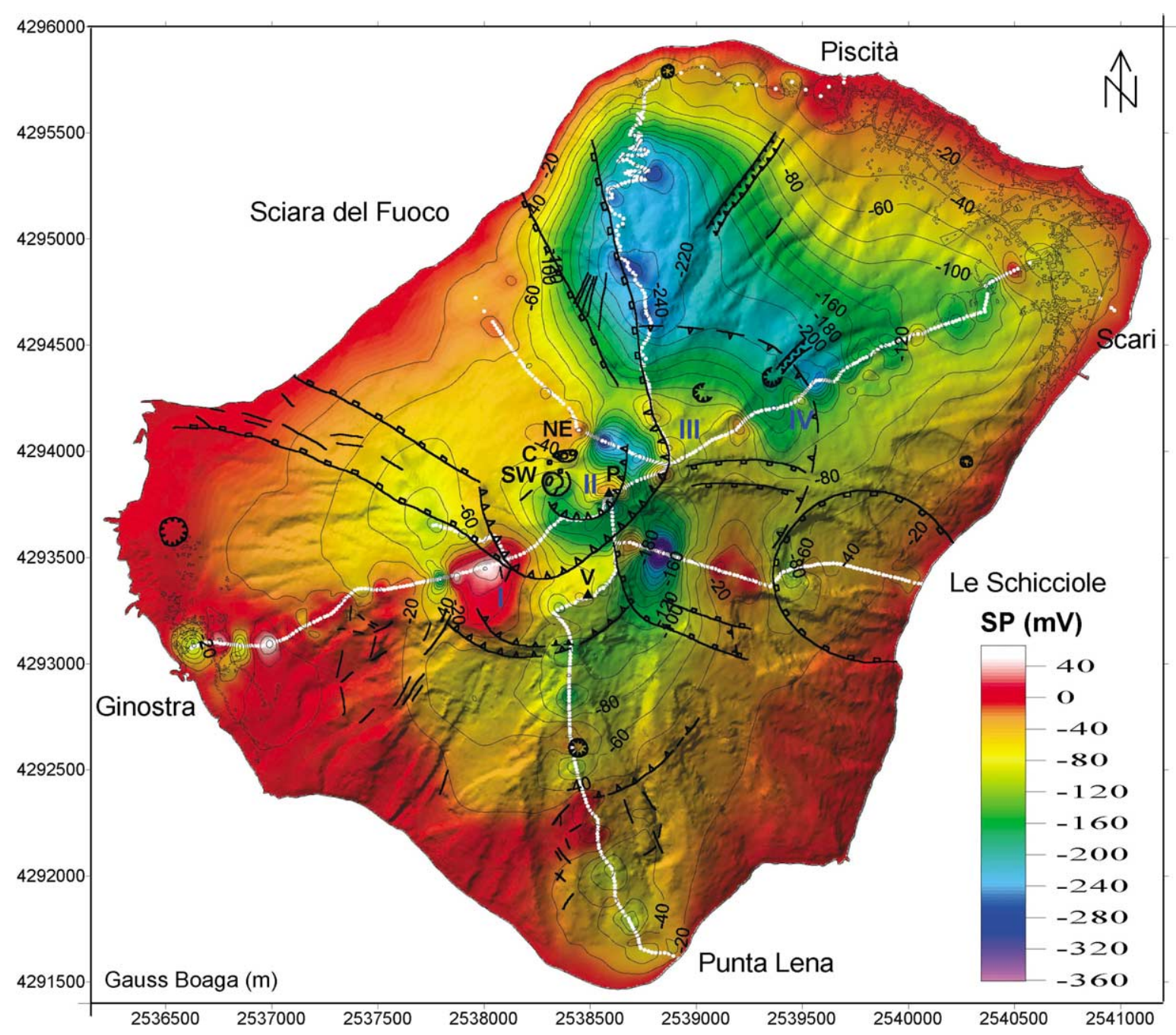

Fig. 2. SP map of Stromboli superimposed on shaded topography and volcano-structural features. White dots are the location of the measurement stations. I, II, III, and IV correspond to the different hydrothermal subsystems defined in Figs. 4 , 5 and 6. Structural and topographic symbols are described in Fig. 1. 
voltmeter, a pair of $\mathrm{Cu} / \mathrm{CuSO}_{4}$ non-polarizing electrodes and an insulated $\mathrm{Cu}$ cable $300 \mathrm{~m}$ long. Since the potential of the sea can be assumed to be constant at the $\mathrm{mV}$ scale, and because all six profiles extend down to the sea, a closure correction (always lower than $50 \mathrm{mV}$ ) could be calculated and applied linearly on the profiles. Gas samples were collected by pumping soil gases through a 3-4 mm diameter copper tube inserted to a depth of $0.5 \mathrm{~m}$. They were injected in glass tubes and later analyzed by gas chromatog- raphy in the laboratory. The analytical uncertainty in the $\mathrm{CO}_{2}$ concentration is $\pm 5 \%$ of the value. All the data were located using a GPS navigation receiver.

Because the data coverage of the island is highly heterogeneous, with a high density of data along the profiles and large areas with no data between them, the interpolation was made in several steps to obtain general $\mathrm{SP}$ and $\mathrm{CO}_{2}$ maps (Figs. 2 and 3). For the SP map (Fig. 2), the potential of the sea was taken as the $0 \mathrm{mV}$

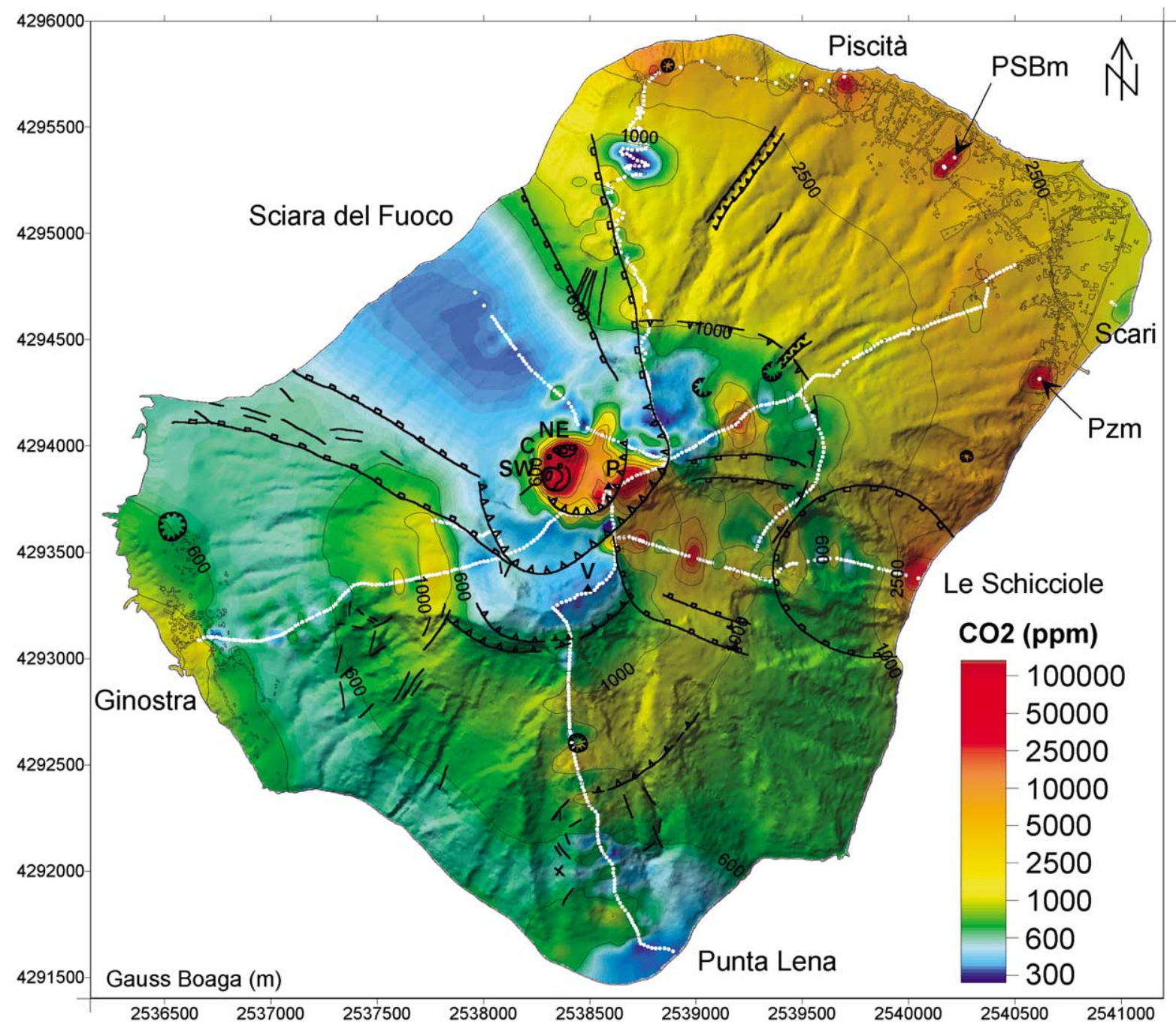

Fig. 3. $\mathrm{CO}_{2}$ concentration map of Stromboli superimposed on shaded topography and volcano-structural features. White dots are the location of the $\mathrm{CO}_{2}$ sampling stations. PSBm and Pzm designate the Piscità-San Bartolo and Pizzillo mofette areas, respectively. Structural and topographic symbol are described in Fig. 1. 
reference. The areas covered by the sea were therefore assigned a value of $0 \mathrm{mV}$. In a second step, an SP map of the entire area was constructed using a wide mesh $(200 \mathrm{~m}$, i.e. 10 times larger than the sampling rate along the profiles) for interpolation. In a last step, a $50 \mathrm{~m}$ square mesh SP map was constructed, using the data along the profiles, $0 \mathrm{mV}$ values for the areas covered by the sea and the grid values of the large mesh $(200 \mathrm{~m})$ SP map. This procedure allowed us to obtain a map with detail along the profiles and an interpolation, at the scale of the island, that is commensurate with the available data. A similar procedure was used to calculate the $\mathrm{CO}_{2}$ map (Fig. 3), except that (1) the sea values were not fixed, (2) high $\mathrm{CO}_{2}$ concentrations values were assigned to the SW, $\mathrm{C}$ and $\mathrm{NE}$ active craters to avoid the unrealistically low values obtained from a raw interpolation of the data in an area where degassing is obviously very high and (3) the interpolation has been constrained to avoid an unrealistic extent of the anomalies related to the very local mofettes of Piscità-San Bartolo and Pizzillo (PSBm and Pzm, respectively, in Fig. 3).

\section{Results}

\subsection{SP survey}

SP anomalies on volcanoes generally exhibit a large signal/noise ratio and are different on the flanks and on the summit area. On the flanks, a linear reverse relationship between SP and altitude is often observed (Corwin and Hoover, 1979; Jackson and Kauahikaua, 1987; Lénat, 1987; Aubert and Yéné Atangana, 1996). This phenomenon is thought to be related to a thickness increase of the vadose zone with altitude ( $\mathrm{Za}$ blocki, 1978). At the Kilauea volcano, Jackson and Kauahikaua (1987) have shown that this relationship allows the definition of the water table depth. The gradient linking SP to the depth of the water table commonly ranges from -1.5 up to about $-5 \mathrm{mV} / \mathrm{m}$. Such zones are regarded as purely hydrogeological zones. By contrast, above the active or central zones of volcanoes, the SP increases regardless of altitude variations. This change in the SP behavior is broadly interpreted in terms of upward hydrothermal circulations (see, for example, Zablocki, 1976). Thus the positive trends in SP anomaly mark underlying hydrothermal zones. Accordingly, when approaching the crater from the flanks, the negative hydrogeological SP gradient is interrupted by a positive trend which marks the beginning of the hydrothermal system. At Stromboli, SP data (Fig. 2) follow only in part this typical pattern: (i) on the flanks, a negative PS/altitude gradient is observed only in the northern part of the island and (ii) at the scale of the data spacing $(20 \mathrm{~m})$, large parts of the profiles show a level of noise, reaching up to $50 \mathrm{mV}$, rarely observed in similar volcanic sites (Figs. 4, 5 and 6). The Stromboli SP anomalies thus appear very unusual and deserve special analysis.

\subsubsection{The Ginostra-Scari profile}

The profile from Ginostra to Scari (Fig. 4) summarizes the SP pattern of Stromboli. Starting from the NE (Scari), we first observe a typical, although weak $(\sim-0.5 \mathrm{mV} / \mathrm{m})$, negative gradient of SP with the altitude, although the data show a large amplitude short-wavelength noise $(\sim 40$ $100 \mathrm{~m}$ in wavelength). This trend is interrupted at A7. Between A7 and A1, we observe a succession of positive anomalies that are only slightly affected by short-wavelength noise. Thus, from Scari to A1, we can identify a typical SP pattern with a hydrogeological zone from Scari to A7 and a hydrothermal zone from A7 (420 m a.s.1.) to A1 (640 $\mathrm{m}$ a.s.1.). The data become atypical on the SW flank, from A1 to Ginostra. A large amplitude short-wavelength noise $(\sim 40-200 \mathrm{~m}$ in wavelength) characterizes the SP data which fluctuate around the electric potential of the sea. Using the usual SP hydrogeological model for the flanks of the volcanoes, this segment should have been interpreted in terms of a shallow water table at a constant depth. This could be possible only if an impermeable layer (e.g. fine-grained pyroclastites or breccias, altered lava flows) will prevent vadose water from flowing down to the basal water table of the island.

If we compare the whole profile with the geology, we note that the limits of the three segments 


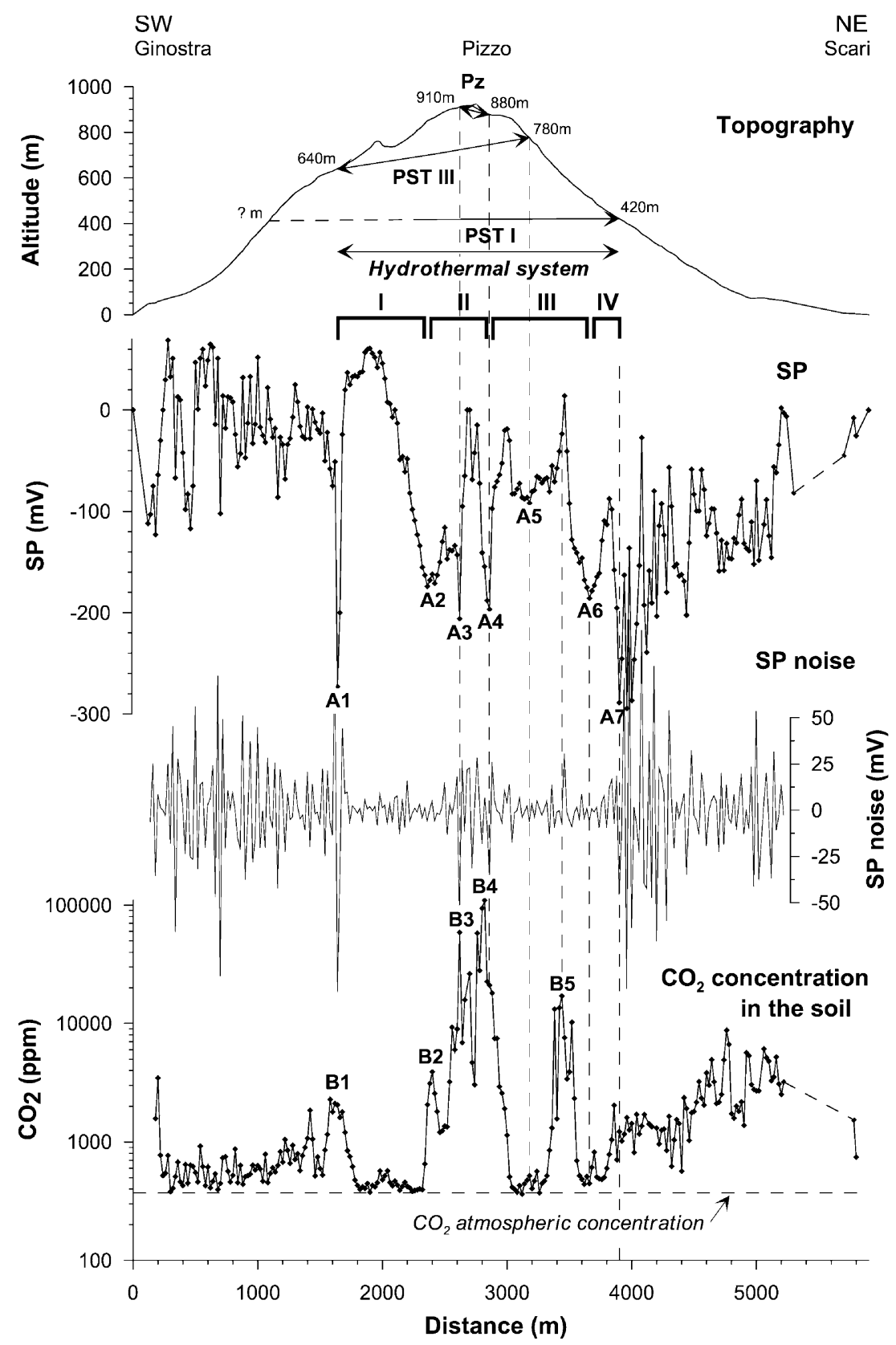

Fig. 4. Comparison between SP and $\mathrm{CO}_{2}$ soil concentration along the Ginostra-Scari profile. A profile of the SP noise is displayed to illustrate noise variation between the flank and the hydrothermal zone (SP noise is calculated by subtracting a smoothed profile (three-point running average window) from the raw profile). PST I and PST III: PaleoStromboli I and III caldera extension. SP minima and $\mathrm{CO}_{2}$ peaks are numbered (see text). I, II, III, IV: hydrothermal subsystems as in Fig. 2. 


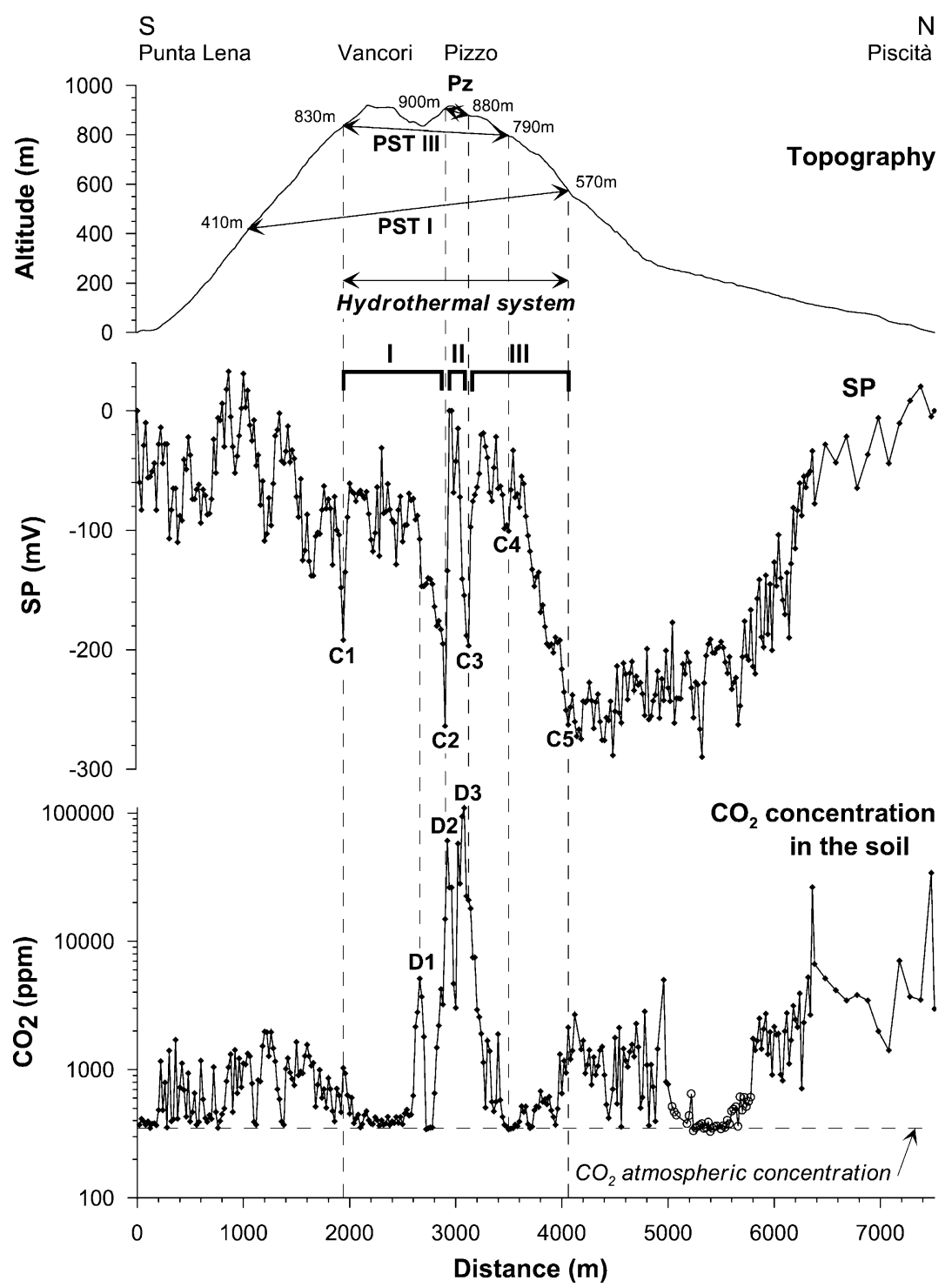

Fig. 5. Comparison between $\mathrm{SP}$ and $\mathrm{CO}_{2}$ soil concentration along the Punta Lena-Piscità profile. Open circles: zone covered with concrete along the tourist trail. Other legends: same as Fig. 4.

of the profile correspond to an observed (A1) and an inferred (A7) caldera limits. This suggests that the hydrothermal system, between A1 and A7, is impounded by structural discontinuities. It is also worthwhile to point out that A1 and A7 are large amplitude SP lows. When A7 low is only the end of the SP decrease with altitude on the NE flank, A1 is a distinct negative anomaly.

The analysis of the Ginostra-Scari profile
(Fig. 4) gives us the criteria to interpret the other two profiles. We distinguished three SP zones: (1) a flank zone which shows the typical SP decrease with altitude, (2) a flank zone with virtually no relationship between SP and altitude and (3) a hydrothermal zone at the summit, characterized by a low level of short-wavelength noise, and a succession of positive anomalies and marked SP lows at its borders. 


\subsubsection{The Punta Lena-Piscità profile}

In the northern half of the profile from Punta Lena to Piscità (Fig. 5), the SP decreases with altitude on the flank $(\sim-0.6 \mathrm{mV} / \mathrm{m})$ and the transition to the hydrothermal zone C5 $(570 \mathrm{~m}$ a.s.l.) is well defined. In the southern part, the profile interpretation is more problematic. Although we observe a slight trend of SP decrease with altitude, data are comparable to the southern part of the Ginostra-Scari profile (Fig. 4). Moreover, the southern limit of the hydrothermal zone is not well defined and it could be represented by the $\mathrm{C} 2$ low. However, we will see that, using both $\mathrm{SP}$ and $\mathrm{CO}_{2}$ data, this limit is more likely to correspond to the $\mathrm{C} 1$ ( $830 \mathrm{~m}$ a.s.l.) low.

\subsubsection{The Sciara del Fuoco-Le Schicciole profile}

The third profile, running from the Sciara del

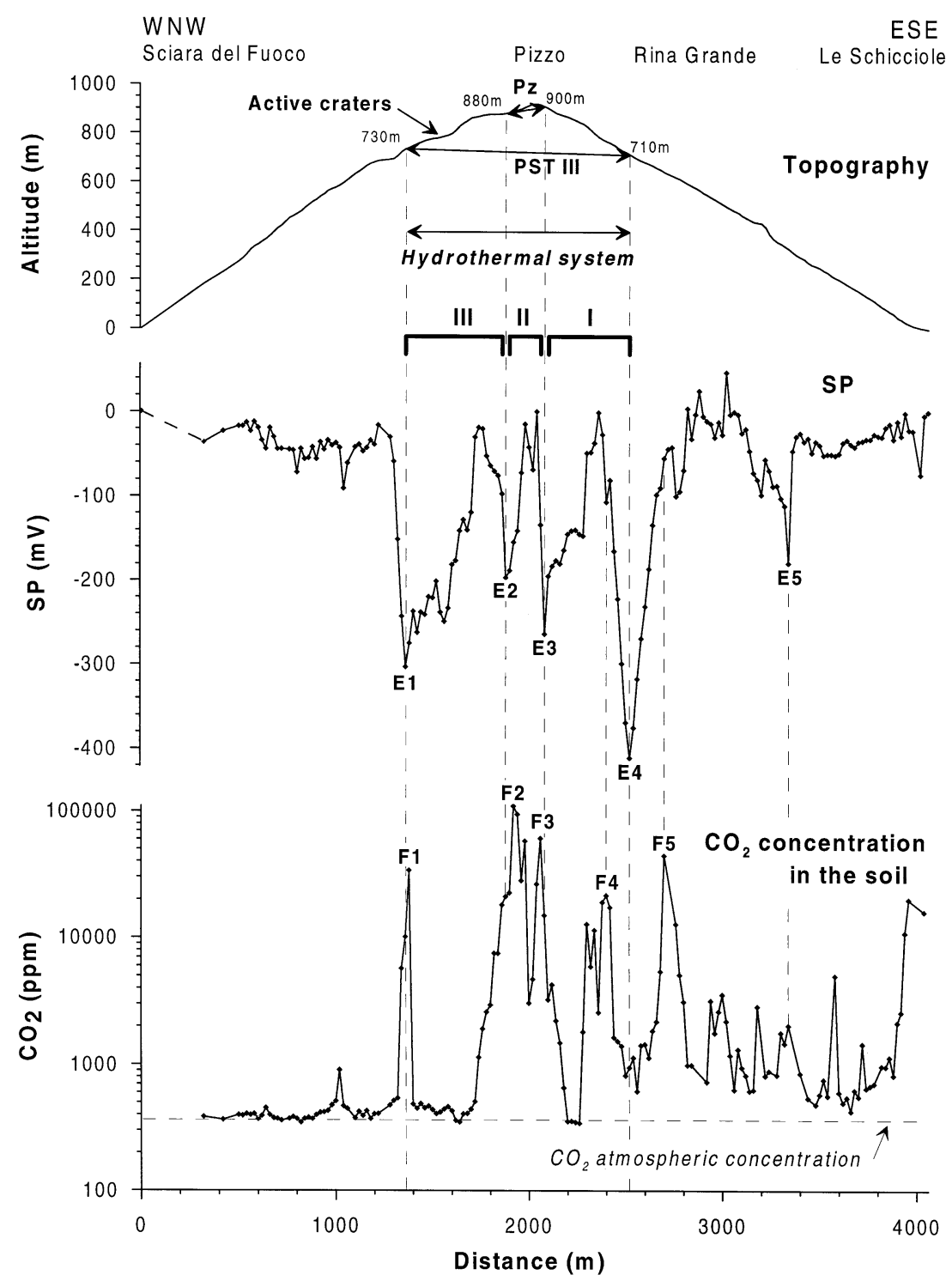

Fig. 6. Comparison between SP and $\mathrm{CO}_{2}$ soil concentration along the Sciara del Fuoco-Le Schicciole profile. Same legend as in Fig. 4. 
Fuoco to Le Schicciole (Fig. 6), follows the same atypical patterns. The SP hydrogeologic zone (with negative SP/altitude gradient) is virtually absent. On both flanks, the SP signal is characterized by a very low level of short-wavelength noise, especially in the Sciara del Fuoco and Le Schicciole sectors, with a slight elevation in the Rina Grande sector to the west of E5. The hydrothermal zone is bracketed by E1 (730 $\mathrm{m}$ a.s.1.) near the summit active craters on the Sciara side and by E4 (710 m a.s.1.) on the Rina Grande-Le Schicciole side.

\section{2. $\mathrm{CO}_{2}$ soil gas survey}

The distribution of $\mathrm{CO}_{2}$ concentration on Stromboli volcano (Fig. 3) shows variations spanning several orders of magnitude, from atmospheric concentrations (350 $\mathrm{ppm})$ up to more than $100000 \mathrm{ppm}$. Like the SP map, the $\mathrm{CO}_{2}$ map reveals large-scale differences: the northern side shows a higher concentration of $\mathrm{CO}_{2}$ than the rest of the island. Along the profiles (Figs. 4,5 and 6), three types of zones can be distinguished according to the $\mathrm{CO}_{2}$ concentration: (1) the concentration is close to that of the atmospheric one; (2) the concentration is significantly higher than the atmosphere; and (3) high concentration peaks. The lower and the upper parts of the edifice can be easily discriminated on the profiles. The upper part is characterized by an association of types 1 and 3 . The flanks correspond mostly to type 2 with a few exceptions, particularly near the sea-shore.

On the northern part of the Ginostra-Scari and Punta Lena-Piscità profiles (Figs. 4 and 5), the $\mathrm{CO}_{2}$ concentration tends to decrease with the altitude, like the SP values do. Only a portion of the Piscità profile departs from this pattern, showing a strong decrease of $\mathrm{CO}_{2}$ (open circles in Fig. 5). This anomaly is thought to correspond to an artefact. This part is along the tourist trail which is covered with concrete in this area. We suspect that the concrete may drastically lower the permeability of the ground, therefore locally reducing the $\mathrm{CO}_{2}$ flux. The southern part of the profiles exhibits a high level of noise with a concentration of about $600-800 \mathrm{ppm}$. No correlation with alti- tude and no well-defined individual anomalies are observed there. The Sciara del Fuoco-Le Schicciole profile (Fig. 6) is strikingly different from the others with virtually no $\mathrm{CO}_{2}$ emanations (type 1) in the Sciara del Fuoco. In the Rina Grande-Le Schicciole area, $\mathrm{CO}_{2}$ concentration is high and a succession of individual short-wavelength anomalies $(\sim 140-200 \mathrm{~m})$ can be defined. Very high $\mathrm{CO}_{2}$ concentration is observed near the sea-shore on all the profiles, except for the Punta Lena and the Sciara del Fuoco profiles. The highest values are found in the north and the northeast areas, and particularly in the PSBm and Pzm areas (in Fig. 3). These two areas are well known by Stromboli inhabitants. In the PSBm area, steam, visible only during the cold winter season, rises from an apparently recent fracture. In the Pzm area, a series of small holes, approximately $1 \mathrm{~m}$ in diameter, are observed. Dead insects are frequently found inside.

\subsection{Comparison between SP measurements and $\mathrm{CO}_{2}$ concentrations}

The SP and $\mathrm{CO}_{2}$ maps of Stromboli (Figs. 2 and 3) show similar large-scale patterns: a difference between the northern and the southern part of the island and the presence of localized anomalies. The flanks of the northern part of the island are characterized by high $\mathrm{CO}_{2}$ emanation and by the typical SP hydrogeological pattern. The other flanks show lower $\mathrm{CO}_{2}$ concentration and no significant SP/altitude gradient. The upper part of the island is characterized by high amplitude anomalies of both parameters. All the profiles (Figs. 4, 5 and 6) show a strong correlation between both $\mathrm{SP}$ and $\mathrm{CO}_{2}$ signals.

We use here the profile from Ginostra to Scari (Fig. 4) as a reference example to analyze this correlation. Starting from Scari, we first observe a decrease in SP and $\mathrm{CO}_{2}$. From A7 to A1, the SP pattern has been interpreted above as the signature of the hydrothermal system. At the same altitude, the $\mathrm{CO}_{2}$ pattern shows a different behavior than on the flanks, with a succession of large anomalies and of zones where the $\mathrm{CO}_{2}$ concentration is close to the background atmospheric value. The main feature is that the peaks of $\mathrm{CO}_{2}$ are 
inversely correlated with the SP peaks. Only B5 (Fig. 4) does not fit this rule. This inverse correlation between the $\mathrm{CO}_{2}$ and the SP fluctuations can be generally observed along all the profiles, with a few exceptions: two $\mathrm{CO}_{2}$ peaks, at $\mathrm{F} 4$ and F5 on Fig. 6, have no negative SP counterpart (D1 in Fig. 5 is located very close to F4 in Fig. 6, and correspond to the same anomaly, see Fig. 3) and the negative SP peak, at E4 in Fig. 6, has no $\mathrm{CO}_{2}$ counterpart.

\section{Interpretation}

Our new set of SP and $\mathrm{CO}_{2}$ data reveals a complex fluid circulation pattern at Stromboli. The main points to be explained are: (1) the summit hydrothermal zone is not centered around the active craters; (2) the marked difference between the north and the other flanks profiles; (3) the large differences in $\mathrm{CO}_{2}$ concentrations between different zones; (4) the large amplitude SP noise in some areas.

\subsection{The hydrothermal system}

There is good evidence of the presence of a hydrothermal system at the summit of Stromboli volcano. This is confirmed by thermal anomalies (Finizola, 1996), locally high $\mathrm{H}_{2} \mathrm{O}$ steam flux (Finizola and Sortino, unpublished data), high $\mathrm{CO}_{2}$ fluxes (Carapezza and Federico, 2000) and hydrothermal alteration of the rocks. Along the summit trail, at $30 \mathrm{~cm}$ depth, temperatures of $70^{\circ} \mathrm{C}$ can be measured as far as $110 \mathrm{~m}$ from the Pizzo. Calcite, Mg-calcite and gypsum, resulting from the hydrothermal alteration of the surface rocks, are largely distributed at the subsurface along the four profiles (Ginostra, Le Schicciole, Scari and Sciara del Fuoco) from the summit to practically $600 \mathrm{~m}$ a.s.1. The signals expected from a simple hydrothermal system would be a positive increase of SP values and, possibly, a high flux of $\mathrm{CO}_{2}$ degassing. Both types of signals are indeed observed in the upper part of the edifice, but they are also associated with prominent $\mathrm{SP}$ and $\mathrm{CO}_{2}$ lows.

Also in this case, the Ginostra-Scari profile
(Fig. 4) can be used as a reference to analyze the SP and $\mathrm{CO}_{2}$ trends in the hydrothermal zone. The SP limits of the system appear to be very sharp. They are assumed to correspond to the deep, short-wavelength SP minima A1 and A7 and to a decrease of the SP noise. Between A1 and A7, 4 individual positive SP anomalies (I to IV) can be distinguished, separated by sharp SP lows (see also the distribution of these anomalies in Fig. 2). The sharp boundaries of the inferred hydrothermal zone suggest that the system is impounded by geological barriers. The latter may be caldera faults because A1 (640 m a.s.1.) and A7 (420 m a.s.1.) coincide quite exactly with the NW continuation of PST III caldera fault and to the inferred traces of the PST I caldera fault, respectively. The boundaries between the individual positive anomalies of the hydrothermal zones can also be related to mapped faults of crater or flank collapses. A2 (850 m a.s.1.) is located on a fault close to the present active craters (6 in Fig. 1). A detailed SP and thermal study of the summit by Finizola et al. (submitted) shows that A3 (910 m a.s.1.) and A4 (880 m a.s.1.) are the boundaries of a hydrothermal system centered on the Pizzo and A4 coincides with the upper limits of the Rina Grande landslide. A5 $(780 \mathrm{~m}$ a.s.l.) could correspond to the buried continuation of PST III caldera fault. Only A6 (510 m a.s.1.) does not have a known structural equivalent. Thus the SP data strongly suggest that the hydrothermal system at the summit of Stromboli is not homogeneous but is partitioned in subsystems by faults. The $\mathrm{CO}_{2}$ exhibits a singular behavior, with very large anomalies separated by zones with virtually no $\mathrm{CO}_{2}$ emanation. As noted earlier, peaks of $\mathrm{CO}_{2}$ correspond, with a few exceptions, to SP lows, whereas SP high values are $\mathrm{CO}_{2}$ free. Only SP anomaly II and part of anomaly III are associated with large $\mathrm{CO}_{2}$ anomalies.

The SP and $\mathrm{CO}_{2}$ anomaly patterns in the hydrothermal zone raise two main problems: (1) why the boundaries of the hydrothermal subsystems are characterized by SP lows and $\mathrm{CO}_{2}$ highs and (2) why the $\mathrm{CO}_{2}$ emanations disappear over most SP highs when one would think of a high $\mathrm{CO}_{2}$ flux in the active zone of the volcano.

The first problem can be explained if the faults 
that separate the hydrothermal subsystems are highly permeable. In this case, the faults act as drains where fluids flow downward by gravitation while gas moves upward. The second problem requires a mechanism to block the $\mathrm{CO}_{2}$ flux at depth. Two mechanisms can be suggested: (1) the presence of an impermeable layer or (2) the capture of $\mathrm{CO}_{2}$ by fluids. In the first hypothesis, the hydrothermal activity would have sealed the rocks at depth, preventing the gas from rising up. Selfsealing is indeed a common feature in hydrothermal systems (see, for example, Browne, 1978; Fisher et al., 1997; Fulignati et al., 1996; Hochstein and Browne, 2000; Harris and Maciejewski, 2000). In this case, the hydrothermal convection would be mostly supplied by meteoric water infiltrated along the permeable structural discontinuities, as suggested above, and convective cells would be generated above the sealed zone. The other hypothesis is to consider that the $\mathrm{CO}_{2}$ flux is dissolved by the hot liquids in the hydrothermal system and is then swept laterally by the convection cells. However, experimental curves of $\mathrm{CO}_{2}$ solubility as a function of temperature (D'Amore and Truesdell, 1988) indicate that the $\mathrm{CO}_{2}$ solubility decreases exponentially from 0 to $170^{\circ} \mathrm{C}$. Moreover, the sharp variation of $\mathrm{CO}_{2}$ at the boundary of the hydrothermal subsystems is hardly compatible with realistic chemical variations in hydrothermal cells. Therefore, only a reduction of permeability due to hydrothermal alteration can be considered as realistic.

The two other profiles can be analyzed using the same criteria as for Ginostra-Scari profile, considering that they all have a part in common in the hydrothermal zone. On Punta Lena-Piscità profile (Fig. 5), the SE limit of the hydrothermal zone is not clearly defined. If we consider the SP profile, the $\mathrm{C} 1$ and $\mathrm{C} 2$ lows could be the equivalent of A1 on Ginostra-Scari profile. The SP pattern between $\mathrm{C} 1$ and $\mathrm{C} 2$ is more similar to the pattern along the flank than to the hydrothermal one. On the other hand, the $\mathrm{CO}_{2}$ pattern advocates for a structural limit in $\mathrm{Cl}(830 \mathrm{~m}$ a.s.1.) that could coincide with the PST III caldera border fault, while C2 (900 m a.s.1.) and C3 (880 m a.s.1.) coincide with the border of the Pizzo hydrothermal system. The C4 minimum (790 m a.s.1.) could correspond to the A5 minimum and C5 (570 $\mathrm{m}$ a.s.1.) coincide with the inferred PST I caldera fault. On the Sciara del Fuoco-Le Schicciole profile (Fig. 6), we can observe that the active craters of Stromboli are practically located on the border of the hydrothermal zone. E1 $(730 \mathrm{~m}$ a.s.1.) could correspond to the buried PST III caldera border fault, while E2 (880 $\mathrm{m}$ a.s.1.) and E3 (900 $\mathrm{m}$ a.s.1.) mark the limits of the Pizzo hydrothermal subsystem. To the east, the limit of the hydrothermal zone is defined by E4 (710 $\mathrm{m}$ a.s.1.) on the SP profile and by F5 (640 m a.s.1.) on the $\mathrm{CO}_{2}$ profile (the $180 \mathrm{~m}$ divergence between E4 and F5 is discussed later). The SP minimum E4 coincides with the inferred concealed fault of PST III caldera. The SP minimum E5 (330 m a.s.1.) could be associated with the head-fault of the Le Schicciole flank collapse.

\subsection{Difference between the northern and the other flanks}

The SP values and $\mathrm{CO}_{2}$ concentrations show a strong difference between the northern and the other profiles. This difference cannot be linked to the surface geology but rather should be related to the internal structure. According to the SP pattern, the northern flank resembles the SP pattern found on most of the volcano flanks. The inverse relationship between SP and the altitude indicates that this flank of the volcano is mostly constituted of porous layers through which vadose water flows down to the basal water table. However, the rest of the island shows a different behavior, probably due to the presence of impermeable layers that prevent the vertical flow of vadose water to the basal water table. In the Ginostra and Punta Lena sectors, the impermeable layers seem to be more or less continuous. This would explain the SP variations along the profiles. The Sciara del Fuoco and Rina Grande-Le Schicciole sectors seem to be slightly different. The SP profile in the Sciara del Fuoco is nearly flat. In hydrogeological terms, this indicates the presence of a continuous impermeable layer at a constant depth. The gliding plane of the Sciara del Fuoco landslide could represent such a layer and could indicate the presence of crushed material rich in 
hydrated and altered minerals such as clay. The Rina Grande-Le Schicciole sector shows a similar trend for SP but a different one for $\mathrm{CO}_{2}$. Uphill, the Rina Grande zone shows more variations in SP. In fact, this area, characterized by large nested flank landslides, is apparently more complex than the Sciara del Fuoco.

\subsection{Distribution of $\mathrm{CO}_{2}$ emanations}

Very high $\mathrm{CO}_{2}$ concentrations are observed in many areas of Stromboli. This denotes a widespread flux of $\mathrm{CO}_{2}$ with a deep origin. On the contrary, the different concentration between zones must be related to relatively shallow processes like the ones discussed above for the summit hydrothermal zone. Along the flanks, the $\mathrm{CO}_{2}$ distribution more or less mimics the SP trend and therefore supports the presence of permeable and impermeable layers. In general $\mathrm{CO}_{2}$ concentration is high on the porous northern flank and in the highly fractured zones.

\subsection{SP noise variations}

We have already pointed out that the signal/ noise ratio of the SP data of Stromboli is significantly degraded compared to many surveys on other volcanoes. A detailed interpretation of this phenomenon would certainly require more specific studies that are beyond the scope of this work. However, we can use the noise level variation to better constrain our interpretations. The noise level along Ginostra-Scari profile, calculated by subtracting a smoothed profile (three-point running average window) from the raw profile, is illustrated in Fig. 4. We observe a clear threshold between the hydrothermal zone and the flank. A similar observation was made by Dana (1992) on Lamongan volcano (Indonesia). One possible interpretation is to consider a variation in the lithology linked to the hydrothermal alteration. The altered rocks within the geothermal zone could behave more homogeneously with regard to the electric currents than the external unaltered counterpart. Another explanation could be to consider the nature of the rocks. The hydrothermal system seems to be impounded within calderas and craters and the rocks within these subsided structures may be different than the rocks along the flanks.

\section{Discussion}

The extensive and dense coverage of SP and $\mathrm{CO}_{2}$ data allows us to investigate the fluid circulation of the Stromboli island. In the previous sections, we have pointed out that structural lim-

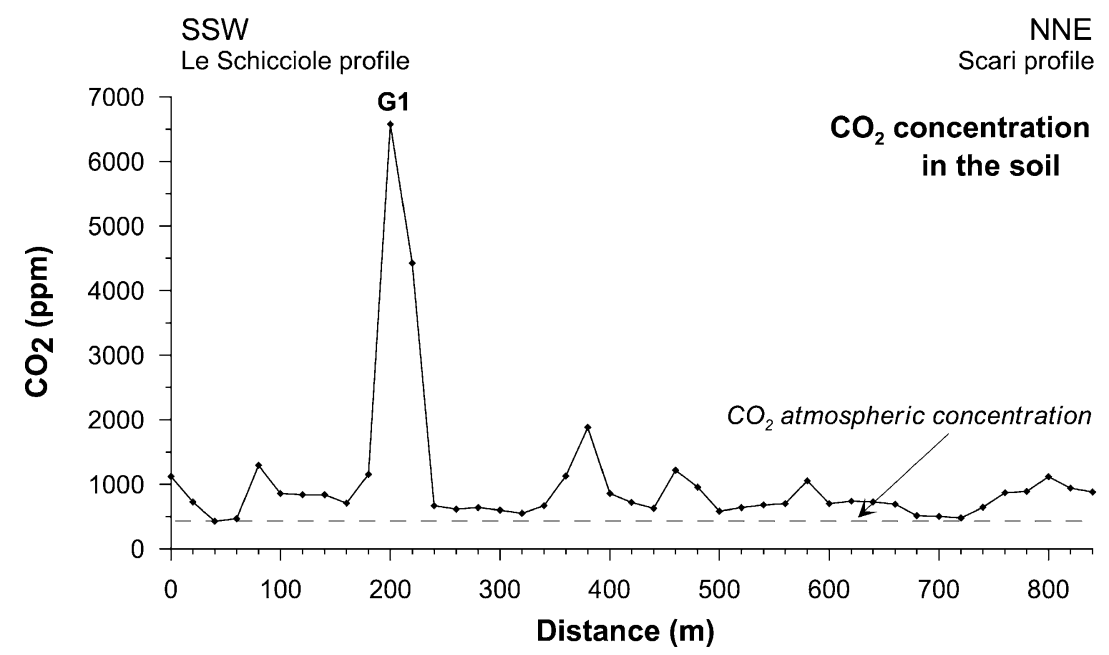

Fig. 7. Profile of $\mathrm{CO}_{2}$ soil concentration between the Le Schicciole and Scari profiles at the nearly constant elevation of $470 \mathrm{~m}$ a.s.1. 
its appear to be the major factor in controlling the fluid circulations and the extension of the hydrothermal system. However, three points deserve special discussion: (1) some $\mathrm{CO}_{2}$ peaks are not correlated with SP minima nor with known structural limits; (2) the hydrothermal system of Stromboli is not limited by a single structure (such as calderas PST I or PST III, flank collapse faults or summit craters); and (3) it is not centered on the presently active craters.

Along the structural limits, short-wavelength SP minima were interpreted in terms of water infiltration, and they coincide with the $\mathrm{CO}_{2}$ highs interpreted in terms of preferential degassing along permeable fault zones. The correlation between SP minima and $\mathrm{CO}_{2}$ peaks is systematic with only three exceptions (B5 in Fig. 4 and F4 and $\mathrm{F} 5$ in Fig. 6). In these cases, $\mathrm{CO}_{2}$ anomalies could be interpreted in terms of regional features. Indeed, B5 and F4 are in line with the PSBm area. In addition, two $\mathrm{CO}_{2}$ emanation anomalies were evidenced by Carapezza and Federico (2000) along this line, on the $\mathrm{Nel} \mathrm{Cannestrà} \mathrm{fissure} \mathrm{and}$ between the latter and PSBm. In order to investigate a possible link between F5 and the Pzm area, an additional $\mathrm{CO}_{2}$ profile was carried out at $470 \mathrm{~m}$ a.s.l. between the Le Schicciole and Scari profiles. The profile (Fig. 7) reveals the presence of a large $\mathrm{CO}_{2}$ anomaly (G1) between the northern wall of the Rina Grande collapse and F5. G1, F5 and Pzm are aligned. These observations strongly suggest that these $\mathrm{CO}_{2}$ anomalies are distributed along two faults oriented $\mathrm{N} 41^{\circ}$ and $\mathrm{N} 64^{\circ}$, respectively (Fig. 8). The $\mathrm{N} 41^{\circ}$ orientation fits with a recent dyke intrusion inferred by Bonaccorso (1998) and with regional stresses deduced from seismic data by Falsaperla et al. (1999). The $\mathrm{N}^{\circ} 4^{\circ}$ coincides with lineaments found in a structural analysis by Zanchi and Francalanci (1989). Also note that the headwalls of five small sector collapses (Fig. 8) between Scari and Rina Grande practically coincide with the inferred fault trace; this could indicate a direct relation between displacements along the fault and collapses on the flank. All these observations thus suggest the presence of two regional faults, decoupled from the volcanic superstructures. These faults allow the degassing of $\mathrm{CO}_{2}$ at the surface and can ac- count for the very high $\mathrm{CO}_{2}$ soil concentrations in PSBm and Pzm.

Unlike most hydrothermal systems previously surveyed using the SP method, Stromboli hydrothermal system presents complex limits and is not centered on the presently active craters (Fig. 8). This divergence may be interpreted in different ways. The internal heat sources may not be limited to the source below the active craters. In the hydrothermal subsystems I and III, the heat flow can be supplied by intrusions emplaced away from the active craters. Intrusions along this direction would be in agreement with the rift zonelike morphology of this part of Stromboli and the 1994 dike intrusion proposed by Bonaccorso (1998). Another possibility is to consider that the heat source corresponds to deep intrusions around the active conduits and that the flow patterns of the hydrothermal subsystems are deformed by structural heterogeneities such as the caldera structures argued above. It is not possible, with the available data, to determine which interpretation is more realistic. In our opinion, the two types of phenomena (scattered intrusions and the influence of the structural heterogeneities) may act concurrently. The extension of the hydrothermal subsystem I would be controlled by PST I and, possibly, partly by the Sciara del Fuoco and the Rina Grande structures, that of the subsystem II by the possible continuity of PST III and Rina Grande structures and that of the subsystem III by PST I and, again, the Sciara del Fuoco and Rina Grande structures. Subsystem IV is probably only related to the immediate surroundings of the eruptive fissure of Nel Cannestrà.

\section{Conclusion}

This work addresses the study of fluids circulation of the Stromboli island by using a dense coverage of SP and $\mathrm{CO}_{2}$ data. Because Stromboli is an isolated volcano with permanent explosive activity and continuous degassing, it can be regarded as a good reference site for comparable studies on other volcanoes. The observed complex patterns of $\mathrm{SP}$ and $\mathrm{CO}_{2}$ anomalies reflect the combined effects of the volcanic and regional 


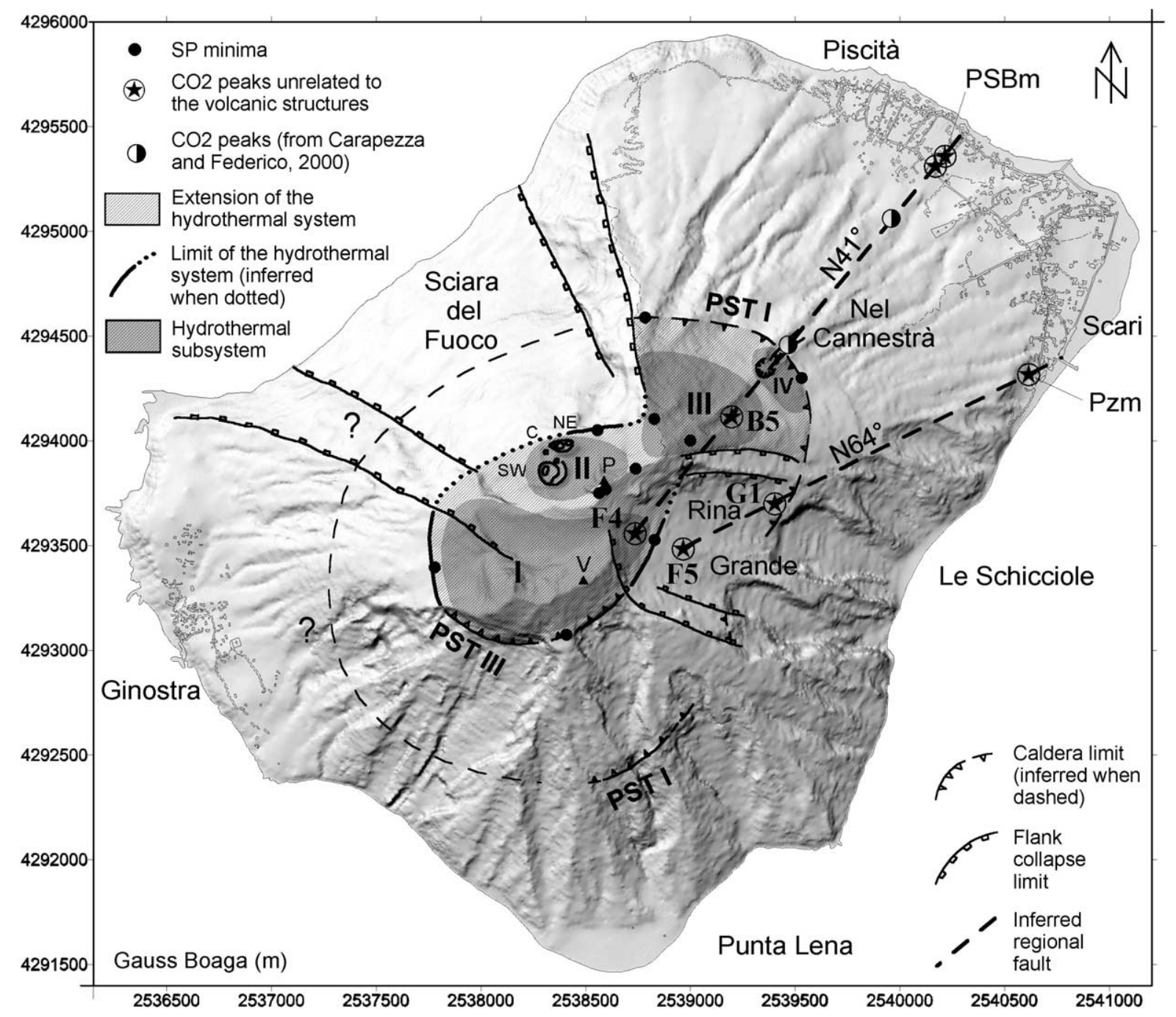

Fig. 8. Map showing the extension of the hydrothermal system of Stromboli and the location of the two inferred regional faults associated with $\mathrm{CO}_{2}$ anomalies.

structures in the control of the fluids circulation and the $\mathrm{CO}_{2}$ degassing. We propose a model involving two systems: (i) a deep $\mathrm{CO}_{2}$ system, corresponding to degassing of magma, and (ii) a more superficial one, corresponding to a hydrothermal system created mostly by meteoric water interacting with the volcanic heat sources. Figure 9 summarizes the interpretation proposed in this work.

The northern side of the island shows a marked difference compared to the rest of the island. The northern flank exhibits (i) a negative SP/altitude gradient, and (ii) a higher level of $\mathrm{CO}_{2}$. The SP pattern advocates for a northern flank constituted mostly of porous layers through which vadose water flows down to the basal water table. The other flanks must contain impermeable layers that do not allow the vertical flow of vadose water. In the Sciara del Fuoco and Rina Grande-Le Schicciole landslide complexes, the gliding planes may constitute these impermeable layers. This general structure of the flanks explains the main SP and 


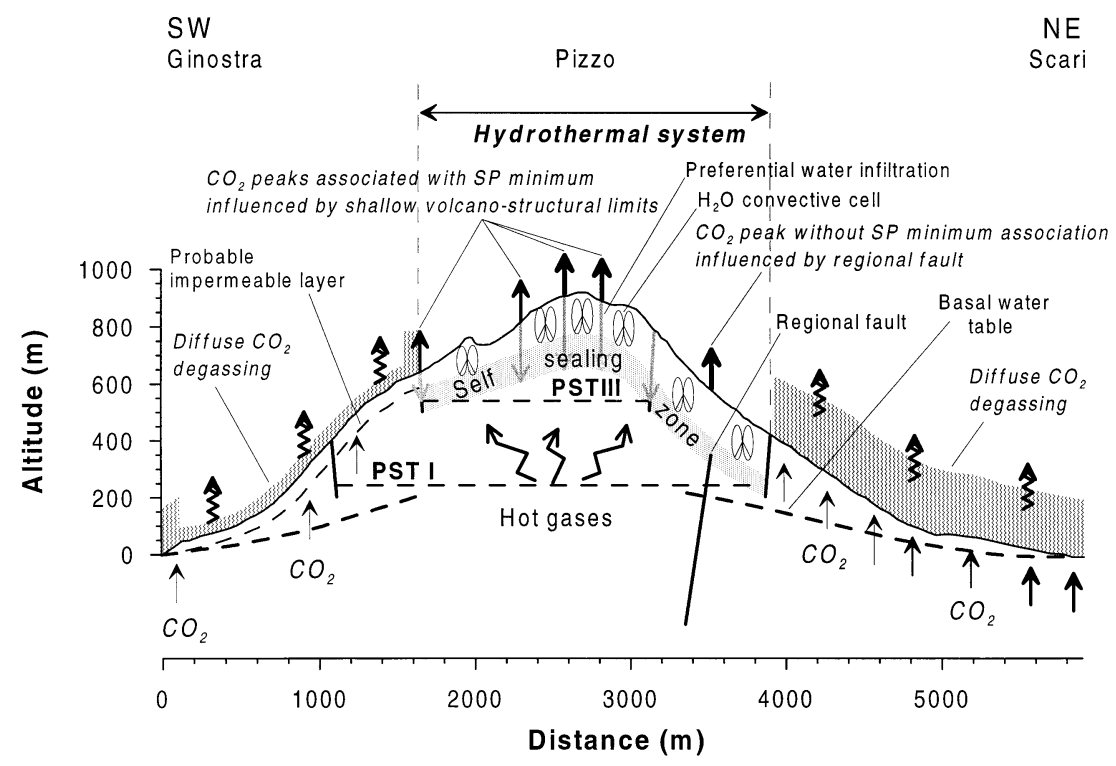

Fig. 9. Interpretative section of fluid circulation and structures of Stromboli along the Ginostra-Scari profile. NB: The depth of the self-sealing zone is not constrained. For clarity it is represented between 100 and $150 \mathrm{~m}$ depth but could be shallower.

$\mathrm{CO}_{2}$ patterns. The general high $\mathrm{CO}_{2}$ concentrations observed in the whole island denote a widespread flux of $\mathrm{CO}_{2}$ of deep origin. At the surface, the $\mathrm{CO}_{2}$ concentration is high on the porous northern flank and lower on the other flanks where the presence of impermeable layers could partially block the $\mathrm{CO}_{2}$ flux.

In the volcanic active summit, the SP and $\mathrm{CO}_{2}$ signals reveal a complex structure of the hydrothermal system. The hydrothermal system is not homogeneous but composed of three main subsystems and a fourth minor one. The limits of the latter are well defined by short-wavelength $(60$ $100 \mathrm{~m}$ ) negative SP anomalies and high peaks of $\mathrm{CO}_{2}$ concentration. These boundaries are found to coincide with faults limiting ancient collapsed calderas, craters and flank landslides. The SP and $\mathrm{CO}_{2}$ signals at these discontinuities can be explained if the fault zones have a high permeability enabling gravitational descent of fluids and rise of gas. In addition, the overall hydrothermal zone is not centered on the present active craters that are actually located near its western border. This discrepancy between the location of the active craters and the extent of the hydrothermal system sug- gests that the internal heat sources may not be restricted to the conduits of the active craters but that intrusions along a $\mathrm{N} 40^{\circ}$ axis may significantly contribute to the heat supply of the hydrothermal system. Alternatively, if the heat sources of the hydrothermal system were limited to the conduits of the active craters, then the flow patterns in the hydrothermal system would be profoundly influenced by the structural heterogeneities of the summit zone, as suggested by the correspondence between the $\mathrm{SP}-\mathrm{CO}_{2}$ signals and the structural limits.

Positive SP anomalies correlated with the virtual absence of $\mathrm{CO}_{2}$ emanation in large areas of the hydrothermal subsystems suggest the self-sealing of the hydrothermal system at depth. Accordingly, the positive SP anomalies would be generated by fluids circulation above the sealed zone which, in turn, would act as a barrier to the $\mathrm{CO}_{2}$ flux.

Finally, we show strong evidences for the presence of two regional faults oriented $\mathrm{N} 41^{\circ}$ and $\mathrm{N} 64^{\circ}$, respectively, decoupled from the volcanic superstructures, along which the $\mathrm{CO}_{2}$ degassing is independent from the volcanic system. 


\section{Acknowledgements}

We sincerely thank Sandrine Poteaux, Virginie Meister, Romain Boyer, Fabrice Mourau, Maria Albo Selma and Laura Turinese for their invaluable help during the summer 1999 and spring 2000 field campaign. Special thanks to Maurizio Ripepe for his warm welcome at the Osservatorio Geofisico di Firenze during the two field campaigns, his detailed and careful reviews of the manuscript and his logistical support with Massimo Della Schiava, especially during the Sciara del Fuoco profile measurements. Reviews by John Stix and Giorgio Capasso have considerably helped to improve the manuscript. A.F. acknowledges the Société de Secours des Amis des Sciences for a research grant.

\section{References}

Allard, P., Carbonnelle, J., Dajlevic, D., Le Bronec, J., Morel, P., Robe, M.C., Maurenas, J.M., Faivre-Pierret, R., Martin, D., Sabroux, J.C., Zettwoog, O., 1991. Eruptive and diffuse emissions of $\mathrm{CO}_{2}$ from Mount Etna. Nature 351, 387-391.

Anza, S., Badalamenti, B., Giammanco, S., Gurrieri, S., Nuccio, P.M., Valenza, M., 1993. Preliminary study on emanation of $\mathrm{CO}_{2}$ from soils in some areas of Mount Etna (Sicily). Acta Vulcanol. 3, 189-193.

Aubert, M., 1999. Practical evaluation of steady heat discharge from dormant active volcanoes: case study of Vulcarolo fissure (Mount Etna, Italy). J. Volcanol. Geotherm. Res. 92, 413-429.

Aubert, M., Kieffer, G., 1984. Evolution d'une intrusion magmatique dans le flanc sud de l'Etna entre juin 1982 et juin 1983. Résultats de potentiel spontané (PS) et essai d'interprétation de l'éruption de 1983. C.R. Acad. Sci. Paris Sér 296, 379-382.

Aubert, M., Baubron, J.C., 1988. Identification of a hidden thermal fissure in a volcanic terrain using a combination of hydrothermal convection indicators and soil-atmosphere analysis. J. Volcanol. Geotherm. Res. 35, 217-225.

Aubert, M., Yéné Atangana, Q., 1996. Self-potential method in hydrogeological exploration of volcanic areas. Ground Water 34, 1010-1016.

Azzaro, R., Branca, S., Giammanco, S., Gurrieri, S., Rasà, R., Valenza, M., 1998. New evidence for the form and extent of the Pernicana Fault System (Mt. Etna) from structural and soil-gas surveying. J. Volcanol. Geotherm. Res. 84, 143-152.

Ballestracci, R., 1982. Self-potential survey near the craters of Stromboli volcano (Italy). Inference for internal structure and eruption mechanism. Bull. Volcanol. 45, 349-365.

Bonaccorso, A., 1998. Evidence of a dyke-sheet intrusion at
Stromboli volcano inferred through continuous tilt. Geophys. Res. Lett. 25, 4225-4228.

Browne, P.R.L., 1978. Hydrothermal alteration in active geothermal fields. Annu. Rev. Earth Planet. Sci. 6, 229-250.

Carapezza, M.L., Federico, C., 2000. The contribution of fluid geochemistry to the volcano monitoring of Stromboli. J. Volcanol. Geotherm. Res. 95, 227-245.

Corwin, R.F., Hoover, D.B., 1979. The Self-Potential method in geothermal exploration. Geophysics 44, 226-245.

D’Alessandro, W., De Domenico, R., Parello, F., Valenza, M., 1992. Soil degassing in tectonically active areas of Mt. Etna. Acta Vulcanol. 2, 175-183.

D'Amore, F., Truesdell, A.H., 1988. A review of solubilities and equilibrum constants for gaseous species of geothermal interest. Sci. Geol. Bull. 41, 309-332.

Dana, Y.N., 1992. Contribution de la méthode de polarisation spontanée (PS) à la connaissance structurale et à la surveillance de quelques volcans indonésiens. Thèse de doctorat, Université Blaise Pascal, Clermont-Ferrand.

Di Maio, R., Mauriello, P., Patella, D., Petrillo, Z., Piscitelli, S., Siniscalchi, A., 1998. Electric and electromagnetic outline of the Mount Somma-Vesuvius structural setting. J. Volcanol. Geotherm. Res. 82, 219-238.

Di Maio, R., Patella, D., 1994. Self-potential anomaly generation in volcanic areas. The Mt. Etna case-history. Acta Vulcanol. 4, 119-124.

Di Maio, R., Patella, D., Siniscalchi, A., 1994. Etna: self-potential, magnetotelluric and geoelectrical measurements. Acta Vulcanol. 6, 30-31.

Etiope, G., Beneduce, P., Calcara, M., Favali, P., Frugoni, F., Schiattarella, M., Smriglio, G., 1999. Structural pattern and $\mathrm{CO}_{2}-\mathrm{CH}_{4}$ degassing of Ustica Island, Southern Tyrrhenian basin. J. Volcanol. Geotherm. Res. 88, 291-304.

Falsaperla, S., Lanzafame, G., Longo, V., Spampinato, S., 1999. Regional stress field in the area of Stromboli (Italy): insights into structural data and crustal tectonic earthquakes. J. Volcanol. Geotherm. Res. 88, 147-166.

Finizola, A., 1996. Etude d'une fissure thermique au Stromboli; interprétation volcanologique et structurale, Mémoire de D.E.A. Processus Magmatiques et Métamorphiques - Volcanologie, Université Blaise Pascal, Clermont-Ferrand, 60 pp.

Finizola, A., Ramos, D., Macedo, O., 1998. Self-potential studies of hydrothermal systems and structure on Misti and Ubinas volcanoes, S. Peru, $23^{\text {rd }}$ EGS Meeting, Ann. Geophys. Suppl. I to Vol. 16 (Solid Earth, Geophysics, and Geodesy), 194.

Finizola, A., Sortino, F., Lénat, J.F., Aubert, M., Ripepe, M., Valenza, M., submitted. The summit hydrothermal system of Stromboli. New insights from self-potential, temperature, $\mathrm{CO}_{2}$ and fumarolic fluids measurements. Structural and monitoring implications. Bull. Volcanol.

Fisher, T.P., Sturchio, N.C., Stix, J., Arehart, G.B., Counce, D., Williams, S.N., 1997. The chemical and isotopic composition of fumarolic gases and spring discharges from Galeras Volcano, Colombia. J. Volcanol. Geotherm. Res. 77, 229253. 
Francalanci, L., 1987. Evoluzione vulcanologica e magmatologica dell'isola di Stromboli (Isole Eolie): Relazioni tra magmatismo calc-alcalino e shoshonitico. Tesi di Dottorato, Dipartimento di Scienze della Terra, Florence, $351 \mathrm{pp}$.

Fulignati, P., Gioncada, A., Sbrana, A., 1996. Modello geologico del sistema idrotermale-magmatico di Vulcano. In: La Volpe, L., Dellino, P., Nuccio, M., Privitera, E., Sbrana, A. (Eds.), Progetto Vulcano. Risultati delle Attività di Ricerca 1993-1995, pp. 97-118.

Gabbianelli, G., Romagnoli, C., Rossi, P.L., Calanchi, N., 1993. Marine geology of the Panarea-Stromboli area (Aeolian Archipelago, Southeastern Tyrrhenian sea). Acta Vulcanol. 3, 11-20.

Giammanco, S., Gurrieri, S., Valenza, M., 1997. Soil $\mathrm{CO}_{2}$ degassing along tectonic structures of Mount Etna (Sicily): the Pernicana fault. Appl. Geochem. 12, 429-436.

Harris, A.J.L., Maciejewski, A.J.H., 2000. Thermal surveys of the Vulcano Fossa fumarole field 1994-1999: evidence for fumarole migration and sealing. J. Volcanol. Geotherm. Res. 77, 229-253.

Hochstein, M.P., Browne, P.R.L., 2000. Surface manifestations of geothermal systems with volcanic heat sources. In: Encyclopedia of Volcanoes. A Press, pp. 835-855.

Hornig-Kjarsgaard, I., Keller, J., Koberski, U., Stadlbauer, E., Francalanci, L., Lenhart, R., 1993. Geology, stratigraphy and volcanological evolution of the island of Stromboli, Aeolian Arc, Italy. Acta Vulcanol. 3, 21-68.

Irwin, W.P., Barnes, I., 1980. Tectonic relations of carbone dioxyde discharges and earthquakes. J. Geophys. Res. 85, 3115-3121.

Jackson, D.B., Kauahikaua, J., 1987. Regional self-potential anomalies at Kilauea volcano: 'Volcanism in Hawaii' chapter 40. US Geol. Surv. Prof. Pap. 1350, 947-959.

Keller, J., Hornig-Kjarsgaard, I., Koberski, U., Stadlbauer, E., Lenhart, R., 1993. Geological map of the island of Stromboli. Acta Vulcanol. 3.

Klusman, R.W., 1993. Soil Gas and Related Methods for Natural Resource Exploration. John Wiley and Sons, New York.

Lénat, J.F., 1987. Structure et dynamique interne d'un volcan basaltique intraplaque océanique: Le Piton de la Fournaise (île de la Réunion). Thèse de doctorat ès sciences. Université Blaise Pascal, Clermont-Ferrand.

Lénat, J.F., Robineau, B., Durand, S., Bachélery, P., 1998. Etude de la zone sommitale du volcan Karthala (Grande
Comore) par polarisation spontanée. C.R. Acad. Sci. 327, 781-788.

Malengreau, B., Lénat, J.F., Bonneville, A., 1994. Cartographie et surveillance temporelle des anomalies de Polarisation Spontanée (PS) sur le Piton de la Fournaise. Bull. Soc. Géol. Fr. 165, 221-232.

Matsushima, N., Michiwaki, M., Okazaki, N., Ichikawa, N., Takagi, A., Nishida, Y., Mori, H.Y., 1990. Self-potential study in volcanic areas - Usu, Hokkaido Komaga-take and Me-akan. J. Fac. Sci. Hokkaido Univ. Ser. VII 8, 465-477.

Nishida, Y., Tomiya, H., 1987. Self-potential studies in volcanic areas - Usu volcano. J. Fac. Sci. Hokkaido Univ. Ser. VII 8, 173-190.

Pasquarè, G., Francalanci, L., Garduno, V.H., Tibaldi, A., 1993. Structure and geologic evolution of the Stromboli volcano, Aeolian Islands, Italy. Acta Vulcanol. 3, 79-89.

Patella, D., 1997. Self-potential global tomography including topographic effects. Geophys. Prosp. 45, 843-863.

Rosi, M., 1980. The Island of Stromboli. Rend. Soc. Ital. Mineral. Petrol. 36, 345-368.

Sugisaki, R., Ido, M., Takeda, H., Isobe, Y., Hayashi, Y., Nakamura, N., Satake, H., Mizutani, Y., 1983. Origin of hydrogen and carbon dioxyde in fault gases and its relation to fault activity. Geology 91, 239-258.

Williams-Jones, G., Stix, J., Heiligmann, M., Charland, A., Sherwood Lollar, B., Arner, N., Garzon, G., Barquero, J., Fernandez, E., 2000. A model of diffuse degassing at three subduction-related volcanoes. Bull. Volcanol. 62, 130-142.

Zablocki, C.J., 1976. Mapping thermal anomalies on an active volcano by the self-potential method, Kilauea, Hawaii. In: Proceedings, 2nd UN Symposium of the development and use of geothermal resources, San Francisco, CA, May 1975, 2, pp. 1299-1309.

Zablocki, C.J., 1978. Streaming potentials resulting from the descent of meteoric water. A possible source mechanism for Kilauean self-potential anomalies. Geotherm. Resour. Counc. Trans. 2, 747-748.

Zanchi, A., Francalanci, L., 1989. Analisi geologico-strutturale dell'isola di Stromboli: alcune considerazioni preliminari. Boll. GNV 5, 1027-1044.

Zlotnicki, J., Michel, S., Annen, C., 1994. Anomalies de polarisation spontanée et systèmes convectifs sur le volcan du Piton de la Fournaise (Ile de la Réunion, France). C.R. Acad. Sci. Paris 318-II, 1325-1331. 